to represent both on a skeleton map as constituting one great range or axis of elevation. The sub-Himalayas consist of rocks of different age from those of the Himalayas, and there is some reason for believing these hills to be of later origin than the main chain; they are therefore represented in our map as a distinct range.

It would take too much space to criticise at any length $\mathrm{Mr}$. Trelawney Saunders's Tibeto-Himalayan system (Geographical Magazine, 1877, p. 173). This system proposes to resolve "the leading outlines of the vast mass of which it treats into four great chains, with their outer slopes and intermediate valleys or plateaus." The chains are called the Kuenluen, KarakorumGangri, and Northern and Southern Himalaya. Now the greater part of the Tibetan area, including, at all events, all east of the meridian of $82^{\circ} \mathrm{E}$. long., is too imperfectly known for any positive assertion to be made as to the number of ranges. In the better known western part of the area one fact alone, the omission to include as one of the main structural features, the range between the Indus and Shayol, shows the description and delineation to be geographically incorrect. The range omitted is at least of equal importance with some of those included. There are many other points open to question, such as the representation of the ranges north and south of Cashmere, as mere continuations of the so-called Northern and Southern Himalaya. In short the system will not fit into the only part of the area with which we have any adequate acquaintance. The accompanying map is doubtless an admirable sketch of the Himalayas as they would be if reconstructed according to $\mathrm{Mr}$. Trelawny Saunders's hypotheses, but I think all who have ever been in those mountains will agree with me that it is not an accurate representation of the range as at present existing.

In conclusion I must decline to reply to any further remarks on this subject from Mr. Trelawney Saunders. It appears to me that Mr. Medlicott and I are entitled to express an independent opinion on the physical geography of the Himalayas without being accused of adopting an antiquated theory. In addition to the geographical data known to $\mathrm{Mr}$. Saunders we have some acquaintance, imperfect, it is true, but still of importance, with the geology, and we have hoth some slight personal knowledge of portions of the range. Under these circumstances we have not adopted the theory advocated by Mr. Saunders simply because we consider it not supported by sufficient evidence.

February 29

W. T. BLANFORD

[This correspondence must end here.-ED.]

\section{Tidal Phenomenon in Lake Constance}

LES mouvements de la glace et de l'eau du lac de Constance décrits par M. S. J. Capper (NATURE, vol. xxi. p. 397) ne doivent pas être rapportés à une marée luni-solaire, ce phénomène étant inappréciable sur un lac dans si petites dimensions. Je me fonde sur les résultats négatifs que j'ai obtenus sur le lac Léman, plus grand en longueur et en surface que le Jac de Constance. En utilisant les tracés de mon limnographe de Morges qui me permet d'évaluer à chaque instant à un millimètre près, la hauteur du lac en choisissant les circonstances les plus favorables, calme absolu de l'eau, et époques de syzygie, je n'ai jamais pu reconnaître de traces de marées luni-solaires.

En revanche les mouvements de balancement de l'eau que nous étudions depuis bien des années sous le nom de seiches, expliqueraient facilement une partie des faits signalés. Les seiches, comme on le sait, sont un mouvement de balancement de toute la masse du lac, qui oscille d'une extrémité à l'autre comme le fait l'eau d'une cuvette on d'une baignoire. Il est vrai que le rhythme des seiches du lac de Constance, pour autant que je le connais par une seule observation du 14 septembre 1874 , n'a qu'une durée d'une heure environ, et non douze heures comme l'indique le batelier de $\mathbf{M}$. Capper. Il serait fort à désirer, pour l'interprétation de phénomène. que $M$. Capper put fournir des données et observations aussi exactes que possible des mouvements qu'il décrit.

Morges (Suisse), 3 mars

\section{The Tay Bridge Storm}

A BRIEF account of the results obtained from the examination of a large number of observations referring to the storm on December 28,1879 , may be of interest even to your non-meteoro. logical readers.

At 6 P.M. on the evening of that day, as will be seen by the accompanying chart, Fig. I, the centre of a cyclone of considerable intensity was situated close to Stornoway. By 8 A,M., the 29 th the centre had moved a distance of about 800 miles to the vicinity of Stockholm, which gives the high mean velocity of 58 miles an hour. But by a method detailed below, it is found that between 6 P.M. and $8 . I_{5}$ P.M. the centre moved along the north of Scotland at the rate of 62 miles an hour, which is, I believe, the highest on record in this country. No precise relation has yet beenttraced between the velocity of a cyclone centre and the strength of the wind in it. In any part of a cyclone the velocity of the wind is undoubtedly principally dependent on the closeness of the isobaric lines, but there is a good deal of evidence to show that when the velocity of the centre is very great, the strength of the wind for any given gradients is in. creased, or at all events becomes more squally and gusty.

In this case the steepest gradient was down the west of Scotland, but only amounted to about $0^{\circ} 13$ inch per 50 miles, which is a very moderate amount for a winter storm.

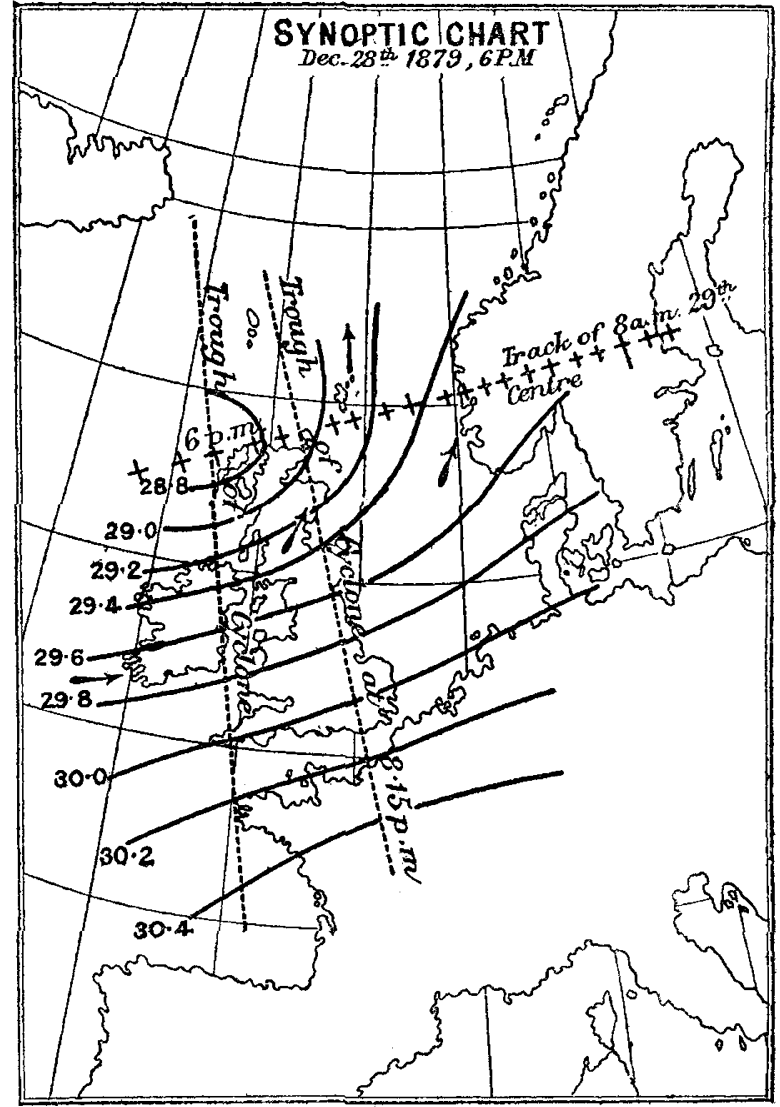

An important result of recent research has been the discovery that every cyclone is divided into two parts by a line drawn through the centre, more or less at right angles to the direction of its motion, at all points in front of which the barometer is falling while it is rising in rear. This line marks out what is called the trough of a cyclone, and while the front and rear present marked contrasts both as regards the in-curvature of the wind, and still more as regards their physical appearance, it is also found that the passage of the actual trough all along its southern portion, except very near the centre, is marked by violent squalls. In the accompanying diagram the position of the trough at $6 \mathrm{P} . \mathrm{M}$. can only be drawn approximately from general considerations as passing down the west of Scotland, but at 8.15 P.M. I have fortunately been able to locate it with great accuracy. At that time the barometer turned upwards at Wick, and almost at the same moment my own barograph in London also turned upwards with the characteristic squall. The line of the trough joining those two points would then be about thirty-three miles east of Dundee, and by combining it with the previous data, the high centre velocity of sixty-two miles an hour was obtained. 